\title{
Multifactorial anticancer effects of digalloyl-resveratrol encompass apoptosis, cell-cycle arrest, and inhibition of lymphendothelial gap formation in vitro
}

\author{
S Madlener', P Saiko², C Vonach',3, K Viola',3, N Huttary', N Stark', R Popescu',4, M Gridling', NT-P Vo',3, \\ I Herbacek ${ }^{5}$, A Davidovits', B Giessrigl', S Venkateswarlu', S Geleff', W Jäger ${ }^{3}$, M Grusch $^{6}$, D Kerjaschki', \\ W Mikulits', ${ }^{5}$ Golakoti ${ }^{6}$, M Fritzer-Szekeres' ${ }^{2}$, T Szekeres ${ }^{2}$ and G Krupitza*, \\ 'Institute of Clinical Pathology, Medical University of Vienna, Vienna, Austria; ${ }^{2}$ Clinical Institute of Medical and Chemical Laboratory Diagnostics, Medical \\ University of Vienna, Vienna, Austria; ${ }^{3}$ Department of Clinical Pharmacy and Diagnostics, University of Vienna, Vienna, Austria; ${ }^{4}$ Department of \\ Pharmacognosy, University of Vienna, Vienna, Austria; ${ }^{5}$ Department of Medicine I, Institute of Cancer Research, Medical University of Vienna, Vienna, \\ Austria; ${ }^{6}$ Laila Impex R\&D Center Unit I, Vijayawada, Andhra Pradesh, India
}

\begin{abstract}
BACKGROUND: Digalloyl-resveratrol (di-GA) is a synthetic compound aimed to combine the biological effects of the plant polyhydroxy phenols gallic acid and resveratrol, which are both radical scavengers and cyclooxygenase inhibitors exhibiting anticancer activity. Their broad spectrum of activities may probably be due to adjacent free hydroxyl groups.

METHODS: Protein activation and expression were analysed by western blotting, deoxyribonucleoside triphosphate levels by HPLC, ribonucleotide reductase activity by ${ }^{14} \mathrm{C}$-cytidine incorporation into nascent DNA and cell-cycle distribution by FACS. Apoptosis was measured by Hoechst 33258/propidium iodide double staining of nuclear chromatin and the formation of gaps into the lymphendothelial barrier in a three-dimensional co-culture model consisting of MCF-7 tumour cell spheroids and human lymphendothelial monolayers.

RESULTS: In HL-60 leukaemia cells, di-GA activated caspase 3 and dose-dependently induced apoptosis. It further inhibited cell-cycle progression in the $\mathrm{Gl}$ phase by four different mechanisms: rapid downregulation of cyclin DI, induction of Chk2 with simultaneous downregulation of Cdc25A, induction of the Cdk-inhibitor $\mathrm{p} 2 \mathrm{I}^{\mathrm{Cip} / \mathrm{Waf}}$ and inhibition of ribonucleotide reductase activity resulting in reduced dCTP and dTTP levels. Furthermore, di-GA inhibited the generation of lymphendothelial gaps by cancer cell spheroidsecreted lipoxygenase metabolites. Lymphendothelial gaps, adjacent to tumour bulks, can be considered as gates facilitating metastatic spread.

CONCLUSION: These data show that di-GA exhibits three distinct anticancer activities: induction of apoptosis, cell-cycle arrest and disruption of cancer cell-induced lymphendothelial disintegration.

British Journal of Cancer (2010) I 02, I36 I-1370. doi:10.1038/sj.bjc.6605656 www.bjcancer.com

(c) 2010 Cancer Research UK
\end{abstract}

Keywords: digalloyl-resveratrol; anti-neoplastic; Cdc25A; ribonucleotide reductase; lymphendothelial retraction

Digalloyl-resveratrol (di-GA) is a synthetic ester of the phytoalexin resveratrol $\left(3,4^{\prime}, 5\right.$-trihydroxystilbene; $\left.\mathrm{RV}\right)$ and the polyhydroxy phenolic compound gallic acid (3,4,5-trihydroxybenzoic acid; GA) (Figure 1). Gallic acid can be found in various natural products, such as green tea, pineapples, bananas, apple peels, red and white wine (Sun et al, 2002; De Beer et al, 2003; Wolfe et al, 2003). Resveratrol is a constituent of red wine and grapes. Both compounds are proposed to contribute to the 'French Paradox', a phenomenon of significantly lower (40\%) heart infarction incidence in the French population, when compared with other European countries or the United States (Richard, 1987; Renaud

\footnotetext{
*Correspondence: Dr G Krupitza;

E-mail: georg.krupitza@meduniwien.ac.at

Received 29 September 2009; revised 6 January 2010; accepted 25 January 2010
}

and De Lorgeril, 1992; Constant, 1997). Gallic acid and RV were also described as excellent free radical scavengers (Inoue et al, 1994; Isuzugawa et al, 2001; Kawada et al, 2001; Salucci et al, 2002; Sohi et al, 2003; Horvath et al, 2005) and as inducers of differentiation and programmed cell death in a variety of tumour cell lines. Other beneficial properties of GA-containing fruit extracts include anti-diabetic and anti-angiogenic effects (Liu et al, 2005; Sridhar et al, 2005). Gallic acid is also present at high concentrations in gallnuts (name), which are proliferations of plant leaves that become elicited by gall wasp exudates to build up a hatchery for their larvae. Thus, the secretion of gall wasps stimulates plant cell growth and overrules homeostasis of the affected leaf area - this is similar to tumour outgrowth. In turn, the plant produces GA, which seems to combat the improper growth signals and re-establishes cell-cycle control. This could at least explain why gallnuts are rich in GA and that gallnuts do not grow beyond a certain size. This cytostatic property of GA - which is amplified in 
A<smiles>O=C(O)c1cc(O)c(O)c(O)c1</smiles>

B<smiles>O=C(Oc1cc(/C=C/c2ccc(O)cc2)cc(OC(=O)c2cc(O)c(O)c(O)c2)c1)c1cc(O)c(O)c(O)c1</smiles>

Figure I Chemical structures of $(\mathbf{A})$ gallic acid (GA) and (B) digalloylresveratrol (di-GA).

di-GA - seems to be one of the cancer-protective principles of a variety of fruits and this could also be developed for adjuvant therapy.

Gallnuts are not used in modern western medicine, but they were mentioned in the first book of 'De Materia Medica' ascribed to Pedanios Dioscurides (the 'Vienna Dioscurides', Austrian National Library, which was written in the sixth century in Konstantinopolis, East Roman Empire). Interestingly, this manuscript claims that gallnuts 'stop the growth of proliferating tissue'. Other studies showed that RV and GA are effective inhibitors of the enzyme ribonucleotide reductase (RR; EC1.17.4.1) (Fontecave et al, 1998; Madlener et al, 2007). Ribonucleotide reductase is significantly upregulated in malignant cells compared to nonmalignant cells. This enzyme catalyses the rate-limiting step of de novo DNA synthesis, which is the reduction of ribonucleotides into the corresponding deoxyribonucleoside triphosphates (dNTPs). This qualifies RR as an excellent target for cancer chemotherapy.

Apart from being a radical scavenger, the multifactorial effects of GA encompass also the inhibition of cyclooxygenases (COXs) and of lipoxygenases (LOXs). Tumours express high levels of COX-2 and 12-LOX (Nie et al, 2003; Pidgeon et al, 2003; Nassar et al, 2007), which metabolise arachidonic acid to prostanoids and to hydroxyeicosatetraenoic acids (12(S)-HETE), respectively (Marks et al, 2000). Certain HETEs function as inter- and intracellular messengers and cause the repulsion of endothelial cells thereby forming gaps in the endothelial cell layer (Ohigashi et al, 1989; Nakamori et al, 1997; Uchide et al, 2007). Further, these gaps may serve as entry ports for adjacent tumour cells into the lymphatic system. Thus, we hypothesised that GA (and di-GA) may inhibit lymphendothelial gap formation. Here we examine the effects of di-GA on apoptosis, cell-cycle progression and lymphendothelial gap formation.

\section{MATERIALS AND METHODS}

\section{Chemicals}

Nordihydroguaiaretic acid (NDGA) was from Cayman Chemical (Ann Arbor, MI, USA); and aspirin, mannitol, probucol, GA and RV were from Sigma-Aldrich (Vienna, Austria). Catalase and carboxy-PTIO were from Calbiochem-Merck Biosciences (Nottingham, UK). Berberine chloride dihydrate (purity 98.92\%) was from Phytolab (Vestenbergsgreuth, Germany). Experimental stock solutions (in DMSO) were prepared always fresh.

Mouse monoclonal anti-Cdc25A (F-6) Cat. No. 7389; antiPARP-1 (F-2) Cat. No. sc-8007; anti-cyclin D1 (M-20) Cat. No. sc718; anti-cyclin E (M20) Cat. No. sc-481 and anti-p21 Cip/Waf (C-19) Cat. No. sc-397 antibodies were from Santa Cruz Biotechnology Inc. (Heidelberg, Germany). Polyclonal anti-phospho-Cdc25A (Ser17) Cat. No. ab18321 antibody was from Abcam (Cambridge, UK); and monoclonal anti-p34 ${ }^{\mathrm{Cdc2}}$ Cat. No. C3085 and anti- $\beta$-actin (AC15) Cat. No. A5441 antibodies were from Sigma-Aldrich. Rabbit monoclonal anti-cleaved caspase 3 (CPP32) clone C92-605 Cat. No. 58404 antibody was from Research Diagnostics Inc. (Flanders, NJ, USA). Polyclonal anti-MEK 1/2 Cat. No. 9122; antiphospho-MEK 1/2 (Ser217/221) Cat. No. $9121 \mathrm{~m}$; anti-phosphoChk2 (Thr68) Cat. No. 2661; anti-Chk2 Cat. No. 2662 and rabbit monoclonal anti-p44/42 MAP Kinase (137F5) Cat. No. 4695; anti-phospho-Cdc2 (Tyr15) Cat. No. 4539 and mouse monoclonal anti-phospho-p44/42 MAPK (Thr202/Tyr204) (E10) Cat. No. 9106 antibodies were from Cell Signaling Technology Inc. (Danvers, MA, USA). Anti-mouse IgG was from Dako (Vienna, Austria). Anti-rabbit IgG and Amersham ECL - high-performance chemiluminescence film - were from GE Healthcare (Vienna, Austria).

\section{Cell culture}

HL-60 human promyelocytic cells were purchased from ATCC (Wesel, Germany). Cells were grown in RPMI-1640 medium supplemented with $10 \%$ heat-inactivated fetal calf serum, $1 \%$ L-glutamine and $1 \%$ penicillin/streptomycin. MCF-7 cells were grown in McCoy 5A medium containing $10 \%$ fetal calf serum and $1 \%$ penicillin/streptomycin. Human normal lung fibroblasts (HLF) were a generous gift of the Cancer Research Institute of the Medical University of Vienna and were grown in RPMI medium containing $10 \%$ fetal calf serum and $1 \%$ penicillin/ streptomycin. All media, supplements and G418 were obtained from Life Technologies (Lofer, Austria).

Human dermal microvascular endothelial cells (C-12260) were purchased from PromoCell (Heidelberg, Germany). To obtain a population of highly enriched lymphendothelial cells (LECs) dermal microvascular endothelial cells were sorted with polyclonal rabbit anti-human podoplanin antibody and sheep antirabbit dynabeads (M-280; Dynal 11203; Invitrogen, Lofer, Austria). Subsequently, residual cells were sorted with anti-CD31 (Dynal 11128). Incubations were performed at $4{ }^{\circ} \mathrm{C}$ for $30 \mathrm{~min}$. Such isolated LECs were stable transfected with telomerase cDNA and then maintained in EGM2 Mv medium (EBM2-based medium CC3156 and supplement CC4147; Lonza, Walkersville, $\mathrm{MD}$, USA) and G-418 (Schoppmann et al, 2004). All cell types were kept in humidified atmosphere containing $5 \% \mathrm{CO}_{2}$ at $37^{\circ} \mathrm{C}$.

\section{Proliferation inhibition assay}

HL-60 cells were seeded in T-25 tissue culture flasks at a concentration of $1 \times 10^{5}$ per $\mathrm{ml}$ and incubated with increasing concentrations of di-GA $(2.5,5,7.5,10$ and $40 \mu \mathrm{M})$. Cell numbers and $\mathrm{I}_{\mathrm{p}} \mathrm{C}_{50}$ values were determined after 24 and $48 \mathrm{~h}$ using a CC-108 microcellcounter (Sysmex, Kobe, Japan). 


\section{Determination of deoxyribonucleoside triphosphates}

The extraction of cellular dNTPs was performed according to a method described previously (Garrett and Santi, 1979). HL-60 cells $\left(7 \times 10^{7}\right)$ were incubated with 5,10 and $40 \mu \mathrm{M} \mathrm{di}-\mathrm{GA}$ for $24 \mathrm{~h}$. Then, $1 \times 10^{8}$ were centrifuged at 1800 r.p.m. and resuspended in $100 \mu l$ phosphate-buffered saline (PBS) and extracted with $10 \mu$ l trichloroacetic acid. The lysate was rested on ice and neutralised by adding $1.5 \mathrm{vol}$ of freon containing $500 \mu \mathrm{m}$ tri-n-octylamin. Afterwards the lysate was centrifuged (15000 r.p.m. for $4 \mathrm{~min}$ ) and the supernatant was used for periodation $(100 \mu \mathrm{l}$ extract $+30 \mu \mathrm{l} 4 \mathrm{M}$ methylamine $(\mathrm{pH} \mathrm{7.5)}+10 \mu \mathrm{l}$ periodat). Aliquots $(120 \mu \mathrm{l})$ of each sample were analysed using a Merck 'La Chrom' HPLC-system equipped with D-7000 interface, L-7100 pump, L-7200 autosampler and L-7400 UV-detector. Detection time was set at $80 \mathrm{~min}$, the detector operated on $280 \mathrm{~nm}$ for $40 \mathrm{~min}$ and then switched to $260 \mathrm{~nm}$ for another $40 \mathrm{~min}$. Samples were eluted with a $3.2 \mathrm{M}$ ammonium phosphate buffer, $\mathrm{pH} 3.6$ ( $\mathrm{pH}$ adjusted by addition of $\left.3.2 \mathrm{M} \mathrm{H} \mathrm{H}_{3} \mathrm{PO}_{4}\right)$, containing $20 \mathrm{moll}^{-1}$ acetonitrile using a $4.6 \times 250 \mathrm{~mm}$ Partisil 10 SAX column (Whatman Ltd., Kent, UK). Separation was performed at constant ambient temperature and at a flow rate of $2 \mathrm{ml} \mathrm{min}^{-1}$. The concentrations of each dNTP of the experimental samples were then calculated as percent of total area under the control curves. Chemicals were from Sigma-Aldrich and of highest available quality.

\section{Hoechst 33258 and propidium iodide double staining}

The vitality staining was performed according to a protocol described before (Grusch et al, 2002). HL-60 cells $\left(0.4 \times 10^{6}\right.$ per $\mathrm{ml}$ ) were seeded in T-25 tissue culture flasks and exposed to increasing concentrations of di-GA $(2.5,5,7.5,10$ and $40 \mu \mathrm{m})$ for $24 \mathrm{~h}$. Hoechst 33258 and propidium iodide were purchased from Sigma-Aldrich and added directly to the cells at final concentrations of 5 and $2 \mu \mathrm{g} / \mathrm{ml}$, respectively. After $60 \mathrm{~min}$ of incubation at $37^{\circ} \mathrm{C}$, we examined cells with a Zeiss Axiovert fluorescence microscope and a DAPI filter (Carl Zeiss, Jena, Germany). Cells were photographed and analysed by visual examination (not by FACS). This method allows to distinguish between early apoptosis, late apoptosis and necrosis. Cells were judged according to their nuclear morphology and the disintegration of their cell membranes, which is indicated by propidium iodide uptake.

\section{Cell-cycle distribution analysis}

HL-60 cells $\left(0.4 \times 10^{6}\right.$ per ml) were seeded in T-25 tissue culture flasks and incubated with $2.5,5,10$ and $40 \mu \mathrm{M}$ di-GA. After $24 \mathrm{~h}$, cells were harvested, washed with $5 \mathrm{ml}$ cold PBS, centrifuged (600 r.p.m. for $5 \mathrm{~min}$ ) and resuspended and fixed in $3 \mathrm{ml}$ ethanol $(70 \%)$ at $4{ }^{\circ} \mathrm{C}$ for $30 \mathrm{~min}$. After two further washing steps with cold PBS, RNAse A and propidium iodide were added to a final concentration of $50 \mu \mathrm{g} \mathrm{ml}^{-1}$ each and incubated at $4{ }^{\circ} \mathrm{C}$ for $60 \mathrm{~min}$ before analysis on a FACSCalibur flow cytometer (BD Biosciences, San Jose, CA, USA). The cell-cycle distribution was calculated with ModFit LT software (Verity Software House, Topsham, ME, USA).

\section{Determination of RR in situ activity}

Exponentially growing HL-60 cells $\left(5 \times 10^{5}\right)$ were incubated with 1 , 2.5 and $5 \mu \mathrm{M}$ di-GA for $24 \mathrm{~h}$ at $37^{\circ} \mathrm{C}$ in a humidified atmosphere containing $5 \% \mathrm{CO}_{2}$ to assess changes in RR in situ activity. Then, cells were pulsed with ${ }^{14} \mathrm{C}$-cytidine (Sigma-Aldrich; $3 \mu \mathrm{l}$ in a $5 \mathrm{ml}$ cell suspension) at $37^{\circ} \mathrm{C}$ for $30 \mathrm{~min}$, collected by centrifugation (1200 r.p.m. for $5 \mathrm{~min}$ ), washed twice with PBS and processed to extract total genomic DNA. Thereafter, the radioactivity, which became incorporated into genomic DNA, was measured.

\section{Western blotting}

HL-60 cells $\left(1.5 \times 10^{7}\right.$ cells $)$ were seeded into T-75 tissue culture flasks and incubated with $10 \mu \mathrm{M}$ di-GA for $0.5,2,4,8$ and $24 \mathrm{~h}$. Then, $1 \times 10^{6}$ cells were harvested (per experimental point), washed twice with cold PBS, centrifuged at 1000 r.p.m. for $5 \mathrm{~min}$ and lysed in a buffer containing $150 \mathrm{~mm} \mathrm{NaCl}, 50 \mathrm{~mm}$ Tris ( $\mathrm{pH} 8.0$ ), $1 \%$ Triton X-100, $1 \mathrm{~mm}$ phenylmethylsulfonyl fluoride and protease inhibitor cocktail (from a $\times 100$ stock; Sigma-Aldrich). The lysates were centrifuged at $4{ }^{\circ} \mathrm{C}$ for $20 \mathrm{~min}$ (12000 r.p.m.) and supernatants stored at $-20{ }^{\circ} \mathrm{C}$ until further analysis. Equal amounts of protein samples were separated by polyacrylamide gel electrophoresis and electroblotted onto PVDF membranes (Hybond, GE Healthcare) at $4{ }^{\circ} \mathrm{C}$ overnight. Equal sample loading was controlled by staining membranes with Poinceau S (Sigma-Aldrich). After washing with $\mathrm{PBS} / 0.5 \%$ Tween 20 (PBS/T) (pH 7.2) or TBS/0.1\% Tween $20(\mathrm{TBS} / \mathrm{T})(\mathrm{pH} 7.6)$, membranes were blocked for $1 \mathrm{~h}$ in blocking solution (5\% non-fat dry milk in PBS/T or in TBS/T). The membranes were incubated with the first antibody (in blocking solution, dilution $1: 500-1: 1000$ ) by gently rocking at $4{ }^{\circ} \mathrm{C}$ overnight. Thereafter, the membranes were washed with PBS or TBS and further incubated with the second antibody (peroxidaseconjugated goat anti-rabbit IgG or anti-mouse IgG, dilution $1: 2000-1: 5000$ in PBS/T or TBS/T) for $12 \mathrm{~h}$. Chemoluminescence was developed by the ECL detection kit and the exposure of membranes to Amersham Hyperfilms (GE Healthcare).

\section{MCF-7 spheroid generation}

$1.2 \mathrm{~g}$ of autoclaved methyl cellulose (M-0512; Sigma-Aldrich) was resuspended in $100 \mathrm{ml}$ prewarmed McCoy 5A medium (Life Technologies; $1.2 \%$ stock concentration), stirred until the solution turned clear and centrifuged at 4000 r.p.m. (swing out rotor) for $2 \mathrm{~h}$ to pellet undesired debris. Then, $1 \times 10^{5}$ MCF-7 cells were transferred to $15 \mathrm{ml} \mathrm{McCoy} 5 \mathrm{~A}$ medium containing $0.24 \%$ methyl cellulose (final concentration). $150 \mu$ l (containing $\sim 1 \times 10^{3}$ cells) was transferred to each well of a round bottom microtitre plate (96-well) to allow spheroid formation. Cells were allowed to aggregate and grow for 2 days, and then spheroids were sufficiently dense for further manipulations. MCF-7 spheroids had an average diameter of $\sim 300 \mu \mathrm{m}$.

\section{MCF-7 spheroid/LEC monolayer co-cultivation}

LECs were seeded in EGM2 MV medium on 24-well plates and allowed to grow for 2-3 days until confluence. Then, LECs were stained with cytotracker green (concentration $2 \mu \mathrm{g} \mathrm{ml}^{-1}$ final concentration, Molecular Probes-C2925, Invitrogen) at $37^{\circ} \mathrm{C}$ for $90 \mathrm{~min}$ and subsequently rinsed thoroughly. Thereafter, MCF-7 spheroids were washed in EGM2 MV medium to rid off methyl cellulose, and 12 spheroids were carefully transferred using wide bore yellow tips to each well containing LECs.

For those experiments in which inhibitors were used, the indicated inhibitor concentrations (final concentrations) were applied to the spheroids $30 \mathrm{~min}$ prior addition of the spheroids to the LEC layers.

\section{Analysis of gap formation}

LEC areas with spheroids on top were photographed using an FITC filter, which was used to visualise cytotracker (green)-stained LECs underneath the spheroids. Axiovert software (Carl Zeiss) facilitated to measure the gap areas within the LEC layers.

\section{Statistical calculations}

Dose-response curves were calculated using the Prism 4.03 software package (GraphPad, San Diego, CA, USA) and statistical 
significance was determined by two-tailed paired $t$-test (significance $P<0.05)$.

\section{RESULTS}

Quite a few studies on GA and its derivatives, RV and RV analogues were performed in human leukaemia cells (Saiko et al, 2008), because these cells are very sensitive to drugs and therefore advantageous to test the efficacy of novel anticancer compounds. HL-60 cells are particularly useful to discriminate the nuclear morphology of necrotic and apoptotic cells (Grusch et al, 2002) and hence, we used HL-60 cells to study di-GA facilitating the comparability of our results with published data of other GA and RV analogues.

\section{Di-GA induces caspase 3 and apoptosis}

The pro-apoptotic potential of naturally occurring GA was compared to that of synthetic di-GA by incubating HL-60 promyelocytic leukaemia cells to both agents (Figure $2 \mathrm{~A}$ and $\mathrm{B}$ ). Increasing concentrations of GA $(10,20,40$ and $80 \mu \mathrm{M})$ elicited 4 , 10,34 and $60 \%$ apoptosis, respectively. Because the di-GA molecule contains two galloyl residues (as compared to just one gallic acid molecule of GA) we expected that half of the di-GA concentrations would induce similar apoptosis rates as the tested GA concentrations. However, 5, 10 and $40 \mu \mathrm{M}$ di-GA (to compare it to 10,20 and $80 \mu \mathrm{M} \mathrm{GA}$, see above) triggered 12,39 and $84 \%$ apoptosis, respectively. In an earlier study, we showed that 25 and $50 \mu \mathrm{M} \mathrm{RV}$ induced $\sim 18$ and $45 \%$ apoptosis in HL-60 cells, respectively (Horvath et al, 2006). Therefore, the apoptotic efficiency of di-GA is the sum of the apoptotic properties of $2 \times \mathrm{GA}$ plus RV. Apoptosis correlated with the activation of caspase 3 and with the signature type cleavage of PARP into an $85 \mathrm{kDa}$ fragment (Figure 2C). Digalloyl-resveratrol did not induce significant numbers of necrotic cells even at high concentrations (data not shown). The data suggest that di-GA is a potent inducer of apoptosis and significantly more effective than GA alone.

\section{Di-GA inhibits G1-S transition}

HL-60 cells were exposed to increasing concentrations of GA and di-GA and the cell numbers were measured after 24 and $48 \mathrm{~h}$. The percentages of proliferation inhibition were calculated at both time points. Those concentrations that inhibited $50 \%$ proliferation $\left(\mathrm{I}_{\mathrm{p}} \mathrm{C}_{50}\right)$ are shown in Table 1. Digalloyl-resveratrol inhibited proliferation 7-10 times more efficiently than GA during the tested time period. Inhibition of cell proliferation was due to a dose-dependent cell-cycle block in G1 (Figure 3A).

\section{Di-GA modulates mitogenic signalling and the expression of cell-cycle regulators}

We next examined the levels of the cell-cycle inhibitor $\mathrm{p} 21^{\mathrm{Cip} / \mathrm{Waf}}$, which is known to inhibit Cdk2 by blocking its interaction with cyclin E (Jeon et al, 2007). p $21^{\mathrm{Cip} / \mathrm{Waf}}$ was induced within $4 \mathrm{~h}$ (Figure 3B), which was independent of p53, because HL-60 cells are p53 negative (Biroccio et al, 1999). Phosphorylation of Erk1 and MEK, which is indicative for their activation, preceded the increase in $\mathrm{p} 21^{\mathrm{Cip} / \mathrm{Waf}}$ levels. This is consistent with previous reports that MEK-Erk signalling upregulates $\mathrm{p} 21^{\mathrm{Cip} / \mathrm{Wa}}$ (Facchinetti et al, 2004; Park et al, 2004; Perez-Pinera et al, 2006). Phosphorylation of Erk2 (the lower band occurring after 4 and $8 \mathrm{~h}$ ) was simultaneous to $\mathrm{p} 21^{\mathrm{Cip} / \mathrm{Waf}}$ upregulation. Next, we investigated whether the expression of the G1-specific cell-cycle regulators Cdc25A, cyclin D1 and cyclin E was altered by di-GA treatment $(10 \mu \mathrm{M})$. Western blot analyses showed that cyclin D1
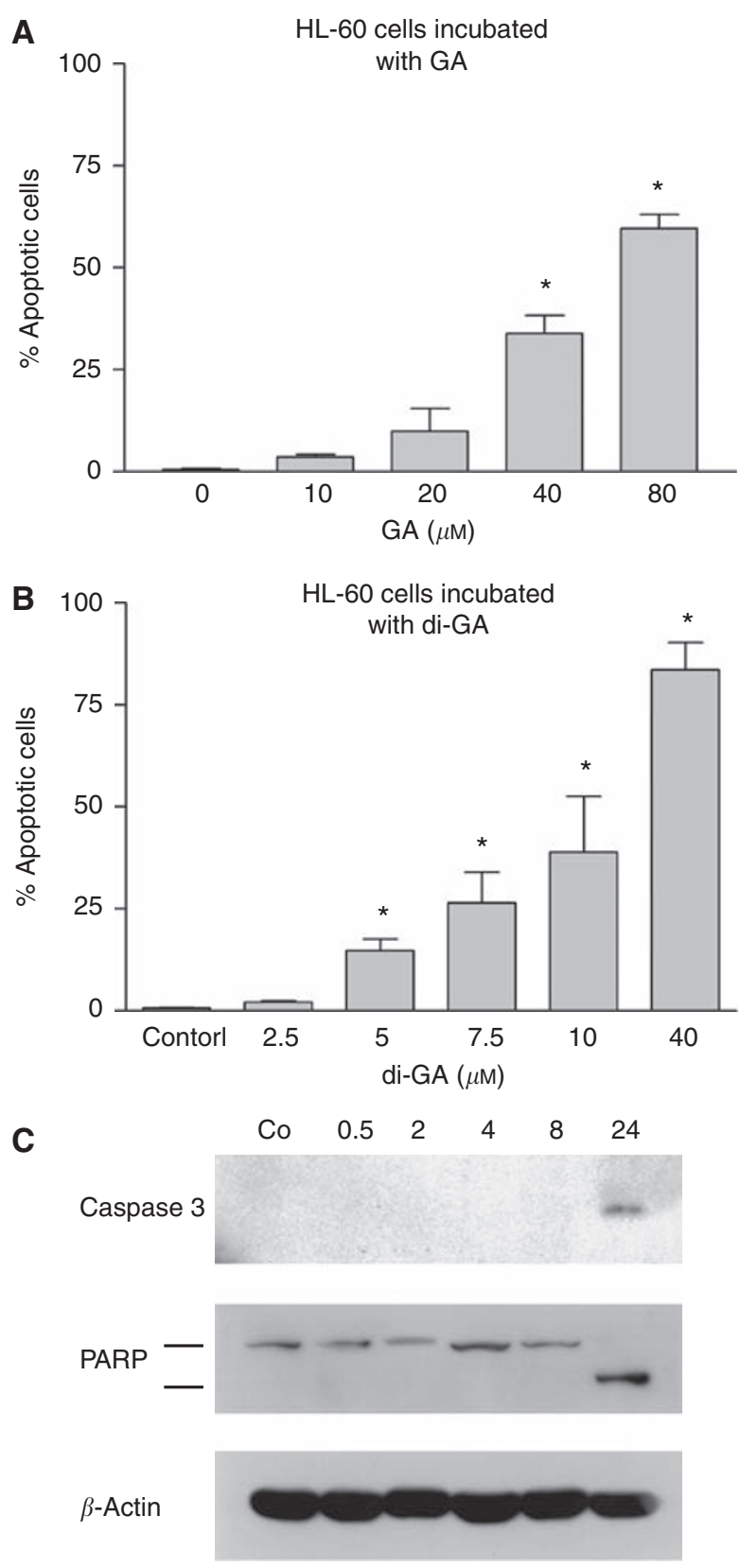

Figure 2 Induction of apoptosis by (A) GA and (B) di-GA in HL-60 cells. Cells were incubated with increasing concentrations of drugs for $24 \mathrm{~h}$, and then double stained with Hoechst 33258 and propidium iodide. Afterwards cells were examined under the microscope with UV light connected to a DAPI filter. Nuclei with a morphological phenotype indicating apoptosis were counted and percentages of apoptotic cells were calculated. Experiments were conducted in triplicate. Error bars indicate s.e.m., asterisks significance $(P<0.05)$. (C) Activation of caspase 3 and cleavage of PARP on treatment with di-GA. Logarithmically growing HL-60 cells were incubated with $10 \mu \mathrm{M}$ di-GA for $0.5,2,4,8$ and $24 \mathrm{~h}$. Afterwards cells were lysed and protein expression was analysed by western blotting. The anti-caspase 3 antibody recognises only the cleaved peptide indicating its activation. Anti-PARP antibody recognises the full-length form (I I $6 \mathrm{kDa})$ and the signature-type cleaved product $(85 \mathrm{kDa})$ that is generated by active caspase 3 . The antibody against $\beta$-actin was used to monitor equal sample loading.

expression decreased after $2 \mathrm{~h}$ and remained suppressed, whereas cyclin E expression persisted (Figure 3C). Cyclin D1 is required for the activation of Cdk4 and Cdk6 (Lingfei et al, 1998; Alao, 2007), 
which altogether is controlled by Cdc25A (Iavarone and Massague, 1997). Digalloyl-resveratrol strongly induced serine 17 (Ser17) phosphorylation of Cdc25A after $4 \mathrm{~h}$. Phosphorylation of Ser17Cdc25A was shown to stabilise this phosphatase at a high activity status specifically in the M phase (Mailand et al, 2002), thereby de-phosphorylating and activating its target Cdk1 (Cdc2). This is mandatory for the transit through the G2-M phase (KarlssonRosenthal and Millar, 2006). Hence, Cdc25A controls not only the G1-S, but also the G2-M phase. Indeed, di-GA caused the de-phosphorylation of Tyr15-Cdc2 indicating that cells entered the mitotic phase. FACS analysis confirmed that $40 \mu \mathrm{m}$ di-GA allowed $\sim 90 \%$ of the cells to pass through $S$ and $M$ phase (likely due to Cdc25A activity) but accumulated in the subsequent G1 phase because cyclin D1 was repressed. Finally, Cdc25A protein

Table I Concentrations of GA and di-GA that inhibit proliferation of HL-60 cells by $50 \%$

\begin{tabular}{lcc}
\hline & $\mathbf{I}_{\mathbf{p}} \mathbf{C}_{\mathbf{5 0}(\mathbf{2 4 h})(\boldsymbol{\mu M})}$ & $\mathrm{I}_{\mathbf{p}} \mathbf{C}_{\mathbf{5 0} \mathbf{( 4 8 \mathrm { h } )}(\boldsymbol{\mu M})}$ \\
\hline GA & 21 & 24 \\
Di-GA & 4 & 2 \\
\hline
\end{tabular}

level decreased after $24 \mathrm{~h}$. This was paralleled by Chk2 activation (indicated by its phosphorylation at Thr68), presumably due to replicatory stress. Chk2 targets $\mathrm{Cdc} 25 \mathrm{~A}$ for proteolytic degradation (Karlsson-Rosenthal and Millar, 2006). In summary, the data suggest that di-GA inhibits cell proliferation by disturbing orchestrated mitogenic signalling.

\section{Di-GA inhibits RR}

Gallic acid is a radical scavenger (Whang et al, 2005) and inhibits $\mathrm{RR}$ through chelating the tyrosyl radical required for RR activity (Madlener et al, 2007). Ribonucleotide reductase is the ratelimiting enzyme for nucleotide metabolism necessary for DNA synthesis during cell division.

Hence, RR activity was investigated by an assay that measures the incorporation of ${ }^{14} \mathrm{C}$-cytidin into genomic DNA. Figure $4 \mathrm{~A}$ shows that ${ }^{14} \mathrm{C}$-cytidin incorporation into genomic DNA decreased with increasing di-GA concentration. Further, RR activity was fully blocked on treatment with $5 \mu \mathrm{M}$ di-GA. At this concentration the dCTP level (but not dTTP and dATP) dropped significantly (Figure 4B). In HT29 colon carcinoma cells, a similar effect of di-GA on RR activity, dCTP, dTTP and dATP levels was observed (Bernhaus et al, 2009).
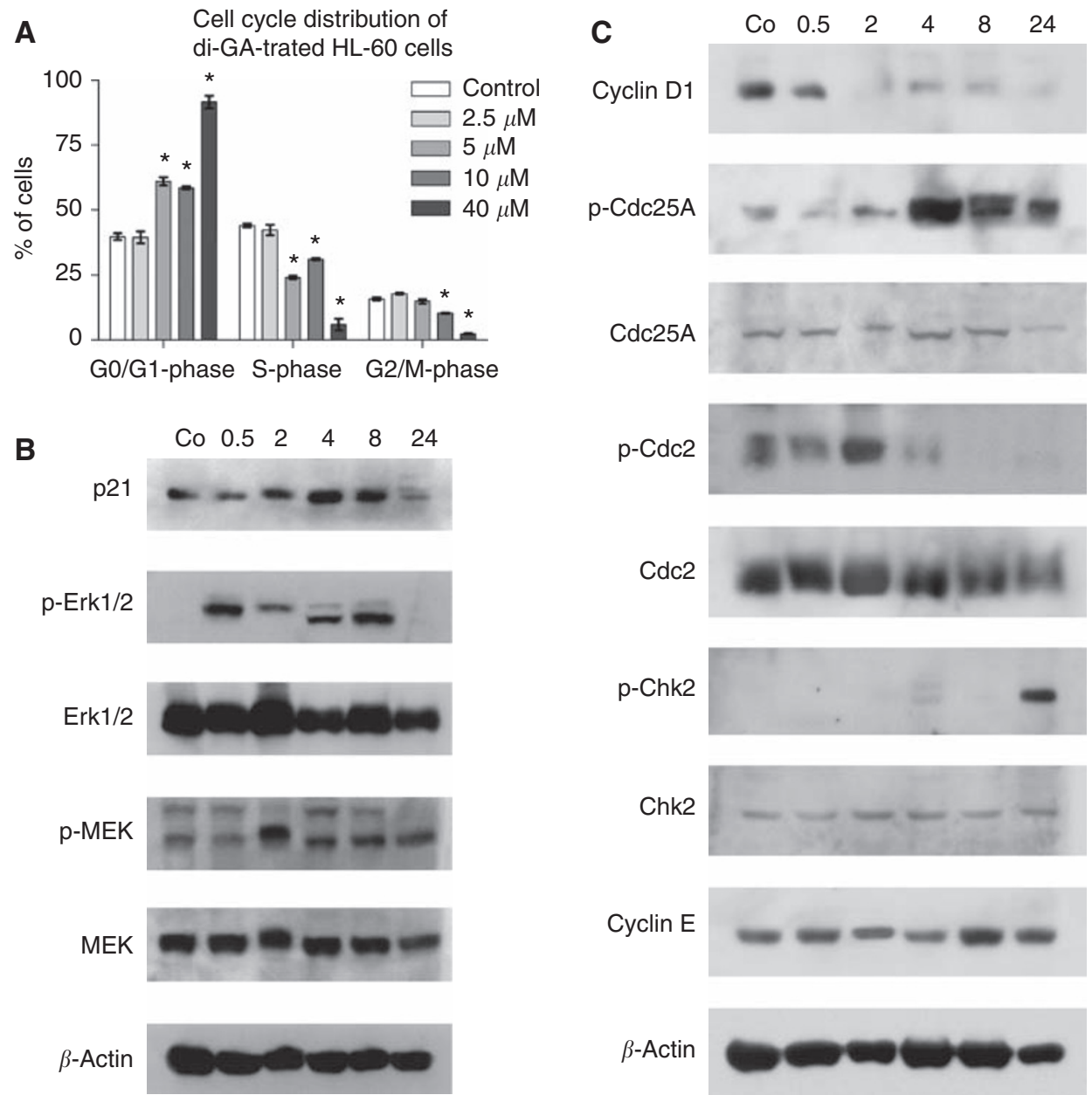

Figure 3 Effect of di-GA on the cell cycle of HL-60 cells. (A) Logarithmically growing HL-60 cells were incubated with increasing concentrations of di-GA for $24 \mathrm{~h}$ and then subjected to FACS analysis. Experiments were conducted in triplicate. Error bars indicate s.e.m., asterisks significance $(P<0.05)$. HL-60 cells were incubated with $10 \mu \mathrm{M}$ di-GA for 0.5, 2, 4, 8 and $24 \mathrm{~h}$, lysed, and the (B) expression of p21 Cip/Waf , the phosphorylation of threonine202/tyrosine204ErkI/2 (p-Erkl/2) and serine2 I7/22I-MEKI/2 (p-MEK), and (C) phosphorylation of threonine68-Chk2 (p-Chk2), serine I7-Cdc25A (p-Cdc25A), tyrosinel 5Cdc2 ( $\mathrm{p}-\mathrm{Cdc} 2)$, and the protein levels of cyclin DI, E were analysed by western blotting. $\beta$-Actin served as loading control. 


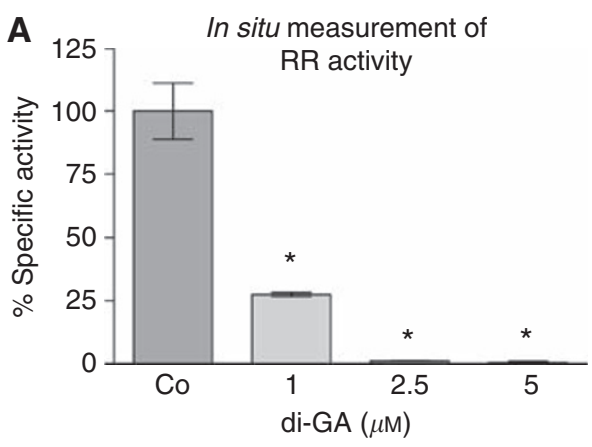

B Concentration of dNTPs in HL60 cells after treatment with di-GA

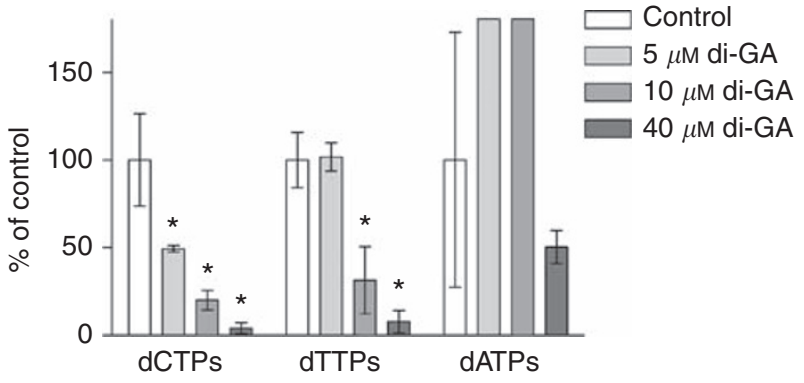

Figure 4 (A) Measurement of the in situ effect of di-GA on ribonucleotide reductase (RR) activity. HL-60 cells were incubated with I, 2.5 and $5 \mu \mathrm{M}$ di-GA for $24 \mathrm{~h}$ at $37^{\circ} \mathrm{C}$ in a humidified atmosphere containing $5 \% \mathrm{CO}_{2}$ to assess changes in RR in situ activity. Then, cells were pulsed with ${ }^{14} \mathrm{C}$-cytidine (Sigma-Aldrich; $3 \mu \mathrm{l}$ in a $5 \mathrm{ml}$ cell suspension) for $30 \mathrm{~min}$ at $37^{\circ} \mathrm{C}$. Afterwards the cells were collected and the radioactivity that became incorporated into genomic DNA was measured. (B) Effect of di-GA on intracellular dNTP pools in HL-60 cells. HL-60 cells were incubated with 5,10 and $40 \mu \mathrm{M}$ di-GA for $24 \mathrm{~h}$. Then the cells were prepared for HPLC analysis and the dNTP levels were determined according to the protocol described in the 'Materials and methods' section. Experiments were conducted in triplicate. Error bars indicate s.e.m., asterisks significance $(P<0.05)$.

\section{Di-GA inhibits lymphendothelial gap formation induced by co-cultivated tumour cell spheroids}

Leukocytes trespass basal membranes and trans-migrate tissues and endothelia as part of their normal physiological function and are therefore, a priori 'invasive'. Hence, HL-60 leukaemia cells are inappropriate to study the pathological invasiveness of cancer cells and the anti-invasive/anti-metastatic potential of di-GA. In contrast, solid tumours acquire an invasive potential in course of cancer progression and this particular cancer cell property has to be studied and combated. We developed a novel bulk invasion assay to establish an in vitro model resembling the pathologic situation of ductal breast cancer cells invading the lymphatic vasculature and to recapitulate the mechanism of metastasis (Ohigashi et al, 1989; Nakamori et al, 1997; Uchide et al, 2007). For this, telomerase immortalised human LECs were grown to confluent monolayers and MCF-7 tumour spheroids (average diameter $\sim 300 \mu \mathrm{m}$, containing $\sim 4000$ cells) were placed on top to mimic tumour intrusion into lymphatics. Lymphendothelial cells were pre-labelled with cyto-tracker (green) immediately before co-cultivation, to monitor presence or absence of LECs underneath tumour spheroids (Figure 5A). Normal HLF spheroids served as negative controls, because these primary cells with limited lifespan (Hayflick limit) are non-malignant and do not invade blood or lymphatic vasculature. After $4 \mathrm{~h}$ of co-cultivation, gaps formed underneath $>99 \%$ of the MCF-7 tumour spheroids (gap area was on average $\sim 1.15 \times 10^{5} \mu \mathrm{m}^{2}$ ) whereas no or only small gaps were formed underneath normal lung fibroblasts. The gap size area was measured underneath at least 12 spheroids and in triplicate experiments. These gaps resemble entry ports for cancer cell bulks invading the lymphatic system, which is now widely accepted to be a route for the spreading of certain cancers (Alitalo et al, 2005; Oliver and Alitalo, 2005; Sipos et al, 2005).

Di-GA inhibited gap formation dose-dependently and maximally by $>60 \%$ (Figure 5B). We have evidence (time-laps movies; data not shown) that gap formation is caused by LEC migration. Berberine was reported to inhibit cell migration and invasion of SCC-4 tongue squamous cancer cells (Ho et al, 2009) and HONE1 nasopharyngeal cancer cells (Tsang et al, 2009). The chemical structure of berberine is reminiscent to parts of di-GA and for control reasons we tested whether berberine had an effect on MCF7-induced LEC behaviour. Berberine dose-dependently inhibited gap formation and this confirmed that the assay was functional and responded according to prediction.

Primary cancers and also MCF-7 breast cancer cells express elevated levels of LOXs, which metabolise arachidonic acid to HETEs (Marks et al, 2000; Nie et al, 2003; Kudryavtsev et al, 2005). The migration of endothelial cells was shown to be mediated by LOXs generating 12(S)-HETE (Ohigashi et al, 1989; Nakamori et al, 1997; Uchide et al, 2007). 12(S)-HETE functions as inter- and intracellular messenger and causes the retraction of endothelial cells, thereby forming gaps into the confluent cell layer. The 12/ 15-LOX inhibitors baicalein $(100 \mu \mathrm{M})$ and NDGA $(50 \mu \mathrm{M})$ reduced the area of MCF-7 spheroid-induced gaps in the LEC monolayers by $\sim 50$ and $60 \%$, respectively. Derivatives of GA are also known to inhibit HETE generating LOXs, and prostanoids generating COXs (Christow et al, 1991; Ha et al, 2004; Kim et al, 2006). However, because aspirin had no effect on gap formation (Figure 5B) the contribution of COXs can be excluded. We also took into account that NDGA, baicalein, GA and di-GA are powerful radical scavengers and antioxidants (Sohi et al, 2003; Floriano-Sanchez et al, 2006). In case LEC gaps were induced by radicals, gap formation should be inhibited by radical scavengers. To test this possibility, we analysed the efficacy of four bona fide ROS scavengers. In particular, we used mannitol, which scavenges the $\mathrm{OH}^{\bullet}$ radical; probucol, which is an effective inhibitor of lipid peroxidation; catalase, which is an $\mathrm{H}_{2} \mathrm{O}_{2}$ catabolising enzyme; and carboxy-PTIO, which scavenges the $\mathrm{NO}^{\bullet}$ radical. These scavengers did not prevent LEC gap formation. Therefore, MCF-7-induced gap formation was independent of a potential radical involvement.

Finally, we tested whether isolated GA and RV inhibited LEC gap formation. Whereas $50 \mu \mathrm{M} \mathrm{RV}$ inhibited gap size by $\sim 25 \%, 80 \mu \mathrm{M}$ GA was ineffective. Therefore, GA did not affect cell migration, which was in contrast to a galloyl glucose derivate that inhibited tube formation of human microvessel endothelial cells (Lee et al, 2004). Methyl gallate influences 5-LOX (Kim et al, 2006) and GA may also inhibit this enzyme. However, 5-LOX did not contribute to LEC gap formation, because $100 \mu \mathrm{M}$ caffeic acid did not reduce gap size (data not shown). This indicated that RV, but not GA, was the inhibitory principle being improved by the higher complex structure of di-GA.

In summary, di-GA dose-dependently inhibited LEC gap formation with an efficiency similar to that of NDGA. The strong anti-invasive property of di-GA is apparently due to the novel chemical structure of the compound, but not due to the GA residues, and only in part due to RV.

\section{DISCUSSION}

Gallic acid is a polyhydroxylated phenol previously known to scavenge radicals, inhibit RR, COXs, LOXs, arrest cell cycle and induce apoptosis (Ha et al, 2004; Faried et al, 2007; Hsu et al, 2007; Madlener et al, 2007).

Here we tested a novel synthetic GA derivate, di-GA, assuming that this compound may exhibit superior activity than GA itself. 

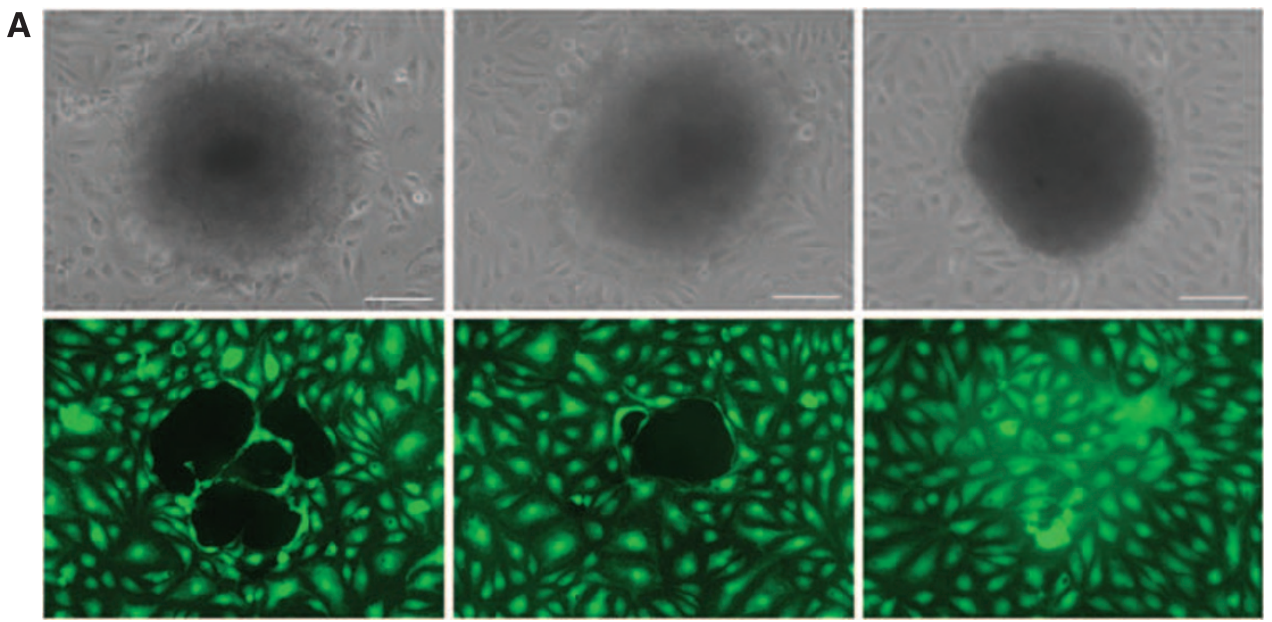

B

3D Spheroids and LEC co-cultivation $(4 \mathrm{~h})$

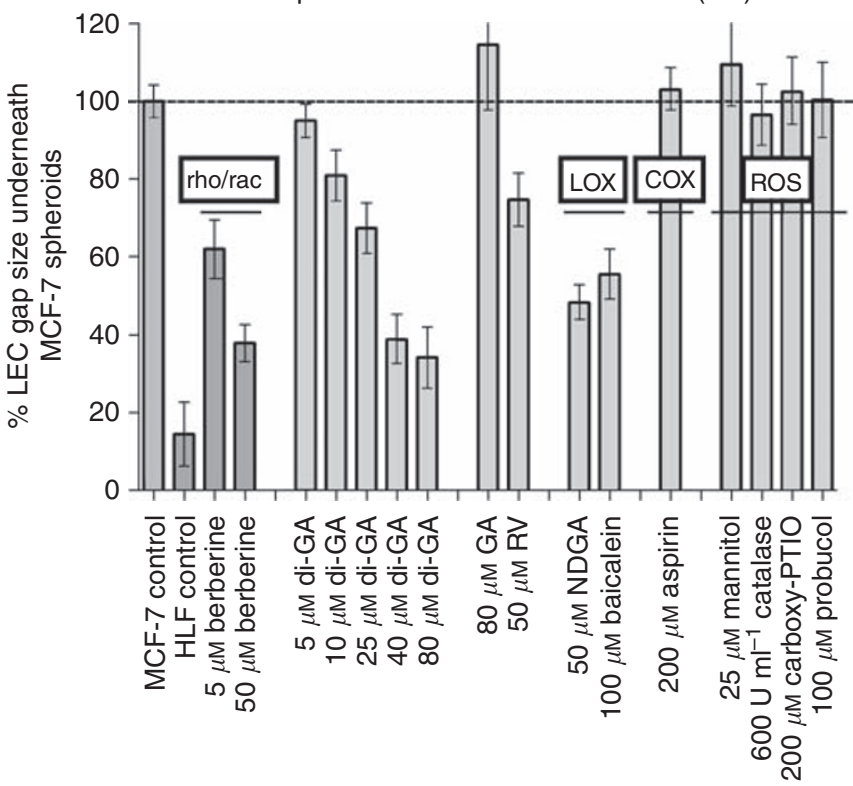

Figure 5 Effect of di-GA on MCF-7 spheroid-induced gap formation in lymphendothelial cell monolayers. (A) LEC monolayers that were exposed to MCF-7 spheroid (left side panels), MCF-7 spheroid treated with $40 \mu$ M di-GA (middle panels) and HLF spheroid (right side panels). Upper panels are phasecontrast micrographs showing the respective spheroids, the panels below show the identical power fields using FITC filter and exhibit green stained LECs underneath the respective spheroids. Bars in the lower right corners of upper panels indicate $100 \mu \mathrm{M}$. (B) MCF-7 tumor spheroids were preincubated with solvent (control), or 5 and $50 \mu \mathrm{M}$ berberine; 5, 10, 25, 40 and $80 \mu \mathrm{M}$ di-GA; $80 \mu \mathrm{M}$ GA; $50 \mu \mathrm{M}$ RV; $50 \mu \mathrm{M}$ NDGA; I00 $\mu \mathrm{M}$ baicalein; $200 \mu \mathrm{M}$ aspirin; $25 \mu \mathrm{M}$ mannitol; $600 \mathrm{U} \mathrm{ml}^{-1}$ catalase; $200 \mu \mathrm{M}$ carboxy-PTIO and $100 \mu \mathrm{M}$ probucol, and then placed on top of cytotracker stained LEC monolayers that were also treated with respective agents for $4 \mathrm{~h}$. Then, the size of the gaps that were formed in the LEC monolayers by MCF-7 spheroids (through repulsion of LECs) was measured using an inverted microscope connected to an FITC filter and equipped with Axiovision 4.5 software (Carl Zeiss). As negative controls normal human lung fibroblast (HLF) spheroids were used. Rho/rac (small GTPases regulating cell migration), LOX (lipoxygenase), COX (cyclooxygenases) and ROS (reactive oxygen species) indicate which mechanisms and phenomena are inhibited by the respective agents. Experiments were conducted in triplicate, and the underneath areas of at least 12 spheroids were analysed. Error bars indicate s.e.m., asterisks significance $(P<0.05)$.

In fact, the pro-apoptotic property of $10 \mu \mathrm{M}$ di-GA exceeded that of $20 \mu \mathrm{M}$ GA by four-fold. Thus, an additional pro-apoptotic mechanism, apart from two galloyl residues, contributed to cell death especially at low concentrations. This is of particular interest because such concentrations can be achieved in humans. The $\mathrm{RV}$ backbone, to which the galloyl residues are connected, may be responsible for the additive effect, because RV was previously reported to induce apoptosis in HL-60 cells (Horvath et al, 2006). The apoptotic activity of di-GA was much higher than the reported RV activity ( $50 \mu \mathrm{M} \mathrm{RV}$ induced $50 \%$ apoptosis in HL-60), but the apoptotic activity of the RV derivative, $3,3^{\prime}, 4,4^{\prime}, 5$, $5^{\prime}$-hexahydroxystilbene (M8) was even higher than that of di-GA (Horvath et al, 2006). In contrast, another RV derivative with anti-neoplastic properties, $N$-hydroxy- $N^{\prime}$-(3,4,5-trimethoxyphenyl)3,4,5-trimethoxy-benzamidine (KITC), induced HL-60 apoptosis less efficiently (Saiko et al, 2007). Digalloyl-resveratrol triggered apoptosis through the caspase 3 pathway yet independent of p53, because HL-60 cells are p53 deficient (Biroccio et al, 1999). Because more than $50 \%$ of all cancer types harbour a defective p53 pathway, which is detrimental to successful therapeutic treatment, compounds that exert anticancer activity independent of p53 are of particular interest for clinical applications.

Another prominent anticancer property of therapeutic drugs is to arrest the cell cycle. This can be achieved by blocking distinct mechanisms such as cell-cycle regulators or enzymes involved in DNA-replicative processes etc. Here we show that di-GA inhibited 
cell proliferation 10-fold more efficiently than GA (Madlener et al, 2007). This again suggests that the RV backbone synergised with the two galloyl residues. Similar to GA, di-GA also inhibited HL-60 cell cycle in G1 (Madlener et al, 2007). Resveratrol and its analogue M8 were shown to inhibit the cell cycle in S phase (Ragione et al, 1998; Horvath et al, 2006) and, therefore, the G1-inhibitory effect of the GA moieties was dominant over that of the RV backbone in the di-GA molecule. Interestingly, also KITC inhibited the HL-60 cell cycle in G1 phase (Saiko et al, 2007). Digalloyl-resveratrol caused cell-cycle arrest by four independent mechanisms:

(i) Di-GA downregulated cyclin D1 and thus presumably inhibited Cdk4 and/or Cdk6. Cyclin D1 was identified as the Prad 1 oncogene, which is overexpressed in many types of cancer (Lingfei et al, 1998; Alao, 2007). Therefore, suppression of cyclin D1 is a relevant target to combat cancer.

(ii) Di-GA induced $\mathrm{p} 21^{\mathrm{Cip} / \mathrm{Waf}}$ and, therefore, affected Cdk2. Both Cdk2- and Cdk4-activity are mandatory for G1-S transit. Hence, blocking $\mathrm{Cdk} 4$ and $\mathrm{Cdk} 2$ inhibits cell division. p21 2 Cip/Waf upregulation was independent of p53, because HL-60 cells are p53 deficient. Consistent with reports that p $21^{\mathrm{Cip} / \mathrm{Waf}}$ is also induced by the MEK-Erk pathway (Facchinetti et al, 2004; Park et al, 2004), we found that di-GA triggered Erk1(p44Thr202)phosphorylation within $30 \mathrm{~min}$ and MEK1(Ser217)-phosphorylation within $2 \mathrm{~h}$. Further, Erk2(p42Tyr204)-phosphorylation occurred at $4 \mathrm{~h}$, which was simultaneous with $\mathrm{p} 21^{\mathrm{Cip} / \mathrm{Waf}}$ induction.

(iii) Di-GA stabilised Cdc25A by Ser17 phosphorylation and forced cells through $S$ and $M$ phase. In consequence, $\sim 90 \%$ of the cells accumulated in the following G1 phase due to cyclin D1 suppression and $\mathrm{p} 21^{\mathrm{Cip} / \mathrm{Waf}}$ induction. This may have resulted in replicative stress because after $24 \mathrm{~h}$ of di-GA treatment Chk2 became activated, which was paralleled by Cdc25A protein degradation. A similar effect was observed on heat shock treatment, which also induces the ATM-Chk2 pathway resulting in the degradation of Cdc25A (Madlener et al, 2009). In contrast, Agarwal et al (2006) observed an almost immediate Cdc25ASer17 phosphorylation and Chk2 activation on treatment of DU145 cells with GA that was not accompanied by degradation of Cdc25A.

(iv) Similar to GA, di-GA inhibited RR most probably by chelating the tyrosyl radical that is required for RR activity (Madlener et al, 2007). Resveratrol inhibits RR through a similar mechanism (Fontecave et al, 1998). At $5 \mu \mathrm{m}$ di-GA inhibited $50 \%$ of dCTP synthesis, whereas it was reported that $50 \mu \mathrm{M}$ GA did not inhibit dCTP synthesis whatsoever (Madlener et al, 2007). Digalloyl-resveratrol inhibited dCTP synthesis also several-fold more efficiently than RV (Horvath et al, 2005). This indicated that the galloyl residues synergised with the RV backbone to inhibit DNA replication.

It has been shown that MCF-7 cells induce gap formation into arterial endothelial cell layers by virtue of 12(S)-HETE secretion, which is generated by LOXs metabolising arachidonic acid (Kudryavtsev et al, 2005; Uchide et al, 2007). Gap formation was due to LEC migration (retraction) but not due to apoptosis of LECs, which was evidenced by microscopic time-laps movies (not shown) and by berberine-mediated inhibition of migration (Ho et al, 2009; Tsang et al, 2009). We extended this cell system using a three-dimensional co-culture model consisting of MCF-7 spheroids and telomerase-immortalised primary human LECs (Schoppmann et al, 2004), because this closely resembles ductal breast cancer bulks intruding the lymphatic vasculature. We showed that MCF-7-triggered lymphendothelial gap formation could be reduced to $40 \%$ by NDGA, which is a potent inhibitor of $12 / 15$-LOXs but also a radical scavenger. Several gallate derivates are known to inhibit LOXs (Christow et al, 1991; Ha et al, 2004; Kim et al, 2006), to scavenge radicals (Whang et al, 2005) and to inhibit COX (Madlener et al, 2007; Kim et al, 2006). However, neither radicals nor COXs contributed to gap formation. Hence, baicalein- and NDGA-mediated inhibition supports the notion that at least $50-$ $60 \%$ of gap formation was due to $12(S)$-HETE generating LOX activity. The property of di-GA that reduced LEC migration was similar to that of NDGA. Also the tube formation of human microvessel endothelial cells, which was inhibited by a galloyl glucose derivate, was most likely due to the inhibition of cell migration (Lee et al, 2004). Because 12/15-LOX contributes to angiogenesis (Nie et al, 2000, 2006; Rose and Connolly, 2000) and tumour metastasis (Liu et al, 1996; Jankun et al, 2006), di-GA may prevent neo-vascularisation of tumours as well as infiltration of cancer cells into the lymphatic vasculature. Another derivate, galloyl glucose, blocked HT-1080 tumour invasion through gelatin by inhibiting matrix metalloprotease-2 (MMP-2) and MMP-9 (Ata et al, 1996). In our system, specific inhibition of MMP-2 and MMP9 with cell permeable small molecules exhibited only a weak effect on MCF-7-mediated gap formation into LEC layers (data not shown). Interestingly, $80 \mu \mathrm{M}$ GA did not decrease lymphendothelial gap formation whereas $50 \mu \mathrm{M} \mathrm{RV}$ inhibited gap formation by $25 \%$ evidencing that the principal inhibitory activity was contributed by $\mathrm{RV}$ and that the superior activity of di-GA was not the sum of RV plus GA, but a new property of its own.

This is analogous to the observation that the RV derivate M8 exhibits not only improved but even new anti-neoplastic properties. In particular, M8 inhibits ROCK1 expression in contrast to RV, which even induces ROCK1 protein levels (Paulitschke et al, 2009). ROCK1 supports migration, invasivity and lymph node metastasis of melanoma cells. M8 inhibits melanoma lymph node metastasis in an scid mouse model by $\sim 50 \%$ at a concentration that is comparable to $50 \mu \mathrm{M}$ used in vitro (Paulitschke et al, 2009). Interestingly, LEC gaps induced by melanoma spheroids could not be inhibited by NDGA or baicalein suggesting that different cancer types invade the lymphatic vasculature by a mechanism different of LOX. In addition to the effects described above, RV and M8 are shown to inhibit NF- $\kappa$ B (Holmes-McNary and Baldwin, 2000; Horvath et al, 2006). In preliminary investigations we found that specific inhibition of NF- $\kappa \mathrm{B}$ by small molecules significantly attenuated LEC gap formation (data not shown). Whether di-GA affects ROCK1 expression and/or NF- $\kappa \mathrm{B}$ translocation remains to be established. DMU-212 (3,4,5,4'-tetramethoxystilbene) is another RV derivate that exerts strong anti-neoplastic effects in breast carcinoma cells by tubulin polymerisation, which is a mechanism not induced by RV (Ma et al, 2008). Other approaches focus on RV analogues with improved cellular uptake properties such as a triacetate form of $\mathrm{RV}$ or vineatrol that both retain the antineoplastic properties of RV (Colin et al, 2009).

In conclusion, we describe three distinct anticancer effects of di-GA: the induction of apoptosis, the inhibition of cell division and the inhibition of gap formation into lymphendothelial layers. Further, we provide mechanistic explanations for the effect of di-GA on apoptosis and cell cycle. For gap formation, we show the affection of cell motility; however, an exact mechanism awaits elucidation.

\section{ACKNOWLEDGEMENTS}

We thank Toni Jäger for preparing the figures, and Professor Max J Scott, Massey University, Palmerston North, NZ, for carefully reading and styling the article. The work was supported by the Unruhe Privatstiftung, the Funds for Innovative and Interdisciplinary Cancer Research, and the Hochschuljubiläumsstiftung der Stadt Wien to GK; the Funds for Innovative and Interdisciplinary Cancer Research, and the Fonds zur Förderung der Wissenschaftlichen Forschung des Bürgermeisters der Bundeshauptstadt Wien, grant number 09059 to MF-S; the Hochschuljubiläumsstiftung der Stadt Wien to TS, and the Austrian Science Fund, FWF, Grant Numbers P19598-B13 and SFB F28, and the Herzfelder Family Foundation (to WM). 


\section{REFERENCES}

Agarwal C, Tyagi A, Agarwal R (2006) Gallic acid causes inactivating phosphorylation of $\mathrm{cdc} 25 \mathrm{~A} / \mathrm{cdc} 25 \mathrm{C}-\mathrm{cdc} 2$ via ATM-Chk2 activation, leading to cell cycle arrest, and induces apoptosis in human prostate carcinoma DU145 cells. Mol Cancer Ther 5(12): 3294-3302

Alao JP (2007) The regulation of cyclin D1 degradation: roles in cancer development and the potential for therapeutic invention. Mol Cancer 6: 24

Alitalo K, Tammela T, Petrova TV (2005) Lymphangiogenesis in development and human disease. Nature 438: 946-953

Ata N, Oku T, Hattori M, Fujii H, Nakajima M, Saiki I (1996) Inhibition by galloylglucose (GG6-10) of tumor invasion through extracellular matrix and gelatinase-mediated degradation of type IV collagens by metastatic tumor cells. Oncol Res 8(12): 503-511

Bernhaus A, Fritzer-Szekeres M, Grusch M, Saiko P, Krupitza G, Venkateswarlu S, Trimurtulu G, Jaeger W, Szekeres T (2009) Digalloylresveratrol, a new phenolic acid derivative induces apoptosis and cell cycle arrest in human HT-29 colon cancer cells. Cancer Lett 274(2): $299-304$

Biroccio A, Del Bufalo D, Ricca A, D’Angelo C, D’Orazi G, Sacchi A, Soddu S, Zupi G (1999) Increase of BCNU sensitivity by wt-p53 gene therapy in glioblastoma lines depends on the administration schedule. Gene Therapy 6: $1064-1072$

Christow S, Luther H, Ludwig P, Gruner S, Schewe T (1991) Actions of gallic esters on the arachidonic acid metabolism of human polymorphonuclear leukocytes. Pharmazie 46(4): 282-283

Colin D, Gimazane A, Lizard G, Izard JC, Solary E, Latruffe N, Delmas D (2009) Effects of resveratrol analogs on cell cycle progression, cell cycle associated proteins and 5fluoro-uracil sensitivity in human derived colon cancer cells. Int J Cancer 124(12): 2780-2788

Constant J (1997) Alcohol, ischemic heart disease, and the French paradox, Coro. Artery Dis 8: 645-649

De Beer D, Joubert E, Gelderblom WC, Manley M (2003) Antioxidant activity of South African red and white cultivar wines: free radical scavenging. J Agric Food Chem 51: $902-909$

Facchinetti MM, De Siervi A, Toskos D, Senderowicz AM (2004) UCN-01induced cell cycle arrest requires the transcriptional induction of p21(waf1/cip1) by activation of mitogen-activated protein/extracellular signal-regulated kinase kinase/extracellular signal-regulated kinase pathway. Cancer Res 64(10): 3629-3637

Faried A, Kurnia D, Faried LS, Usman N, Miyazaki T, Kato H, Kuwano H (2007) Anticancer effects of gallic acid isolated from Indonesian herbal medicine, Phaleria macrocarpa (Scheff.) Boerl, on human cancer cell lines. Int J Oncol 30(3): 605-613

Floriano-Sanchez E, Villanueva C, Medina-Campos ON, Rocha D, Sanchez-Gonzalez DJ, Cardenas-Rodriguez N, Pedraza-Chaverri J (2006) Nordihydroguaiaretic acid is a potent in vitro scavenger of peroxynitrite, singlet oxygen, hydroxyl radical, superoxide anion and hypochlorous acid and prevents in vivo ozone-induced tyrosine nitration in lungs. Free Radical Res 40(5): 523-533

Fontecave M, Lepoivre M, Elleingand E, Gerez C, Guittet O (1998) Resveratrol, a remarkable inhibitor of ribonucleotide reductase. FEBS Lett 421(3): 277-279

Garrett C, Santi DV (1979) A rapid and sensitive high pressure liquid chromatography assay for deoxyribonukleoside trisphosphate in cell extracts. Anal Biochem 99: 268-273

Grusch M, Polgar D, Gfatter S, Leuhuber K, Huettenbrenner S, Leisser C, Fuhrmann G, Kassie F, Steinkellner H, Smid K, Peters GJ, Jayaram HN, Klepal W, Szekeres T, Knasmüller S, Krupitza G (2002) Maintainance of ATP favours apoptosis over necrosis triggered by benzamide riboside. Cell Death Differ 9: 169-178

Ha TJ, Nihei K, Kubo I (2004) Lipoxygenase inhibitory activity of octyl gallate. J Agric Food Chem 52(10): 3177-3181

Ho YT, Yang JS, Li TC, Lin JJ, Lin JG, Lai KC, Ma CY, Wood WG, Chung JG (2009) Berberine suppresses in vitro migration and invasion of human SCC-4 tongue squamous cancer cells through the inhibitions of FAK, IKK, NF-kappaB, u-PA and MMP-2 and -9. Cancer Lett 279(2): 155-162

Holmes-McNary M, Baldwin Jr AS (2000) Chemopreventive properties of trans-resveratrol are associated with inhibition of activation of the IkappaB kinase. Cancer Res 60(13): 3477-3483

Horvath Z, Saiko P, Illmer C, Madlener S, Hoechtl T, Bauer W, Erker T, Jaeger W, Fritzer-Szekeres M, Szekeres T (2005) Synergistic action of resveratrol, an ingredient of wine, with Ara-C and tiazofurin in HL-60 human promyelocytic leukemia cells. Exp Hematol 33(3): 329-335
Horvath Z, Murias M, Saiko P, Erker T, Handler N, Madlener S, Jaeger W, Grusch M, Fritzer-Szekeres M, Krupitza G, Szekeres T (2006) Cytotoxic and biochemical effects of $3,3^{\prime}, 4,4^{\prime}, 5,5^{\prime}$-hexahydroxystilbene, a novel resveratrol analog in HL-60 human promyelocytic leukemia cells. Exp Hematol 34(10): 1377-1384

Hsu CL, Lo WH, Yen GC (2007) Gallic acid induces apoptosis in 3T3-L1 pre-adipocytes via a Fas- and mitochondrial-mediated pathway. J Agric Food Chem 55: 7359-7365

Inoue M, Suzuki R, Koide T, Sakaguchi N, Ogihara Y, Yabu Y (1994) Antioxidant gallic acid, induces apoptosis in HL-60 RG cells. Biochem Biophys Res Commun 204: 898-904

Isuzugawa K, Inoue M, Ogihara Y (2001) Catalase contents in cells determine sensitivity to the apoptosis inducer gallic acid, Biol. Pharm Bull 24: $1022-1026$

Iavarone A, Massague J (1997) Repression of the CDK activator Cdc25A and cell-cycle arrest by cytokine TGF-beta in cells lacking the CDK inhibitor p15. Nature 387: 417-422

Jankun J, Aleem AM, Malgorzewicz S, Szkudlarek M, Zavodszky MI, Dewitt DL, Feig M, Selman SH, Skrzypczak-Jankun E (2006) Synthetic curcuminoids modulate the arachidonic acid metabolism of human platelet 12-lipoxygenase and reduce sprout formation of human endothelial cells. Mol Cancer Ther 5(5): $1371-1382$

Jeon Y, Yong Lee K, Ji Ko M, Sun Lee Y, Kang S, Su Hwang D (2007) Human TopBP1 participates in cyclin E/CDK2 activation and preinitiation complex assembly during $\mathrm{G}_{1} / \mathrm{S}$ transition. J Biol Chem 282(20): $14882-14890$

Karlsson-Rosenthal C, Millar JB (2006) Cdc25: mechanisms of checkpoint inhibition and recovery. Trends Cell Biol 16(6): 285-292

Kawada M, Ohno Y, Ri Y, Ikoma T, Yuugetu H, Asai T, Watanabe M, Yasuda N, Akao S, Takemura G, Minatoguchi S, Gotoh K, Fujiwara H, Fukuda K (2001) Anti-tumor effects of gallic acid on LL-2 lung cancer cells transplanted in mice. Anticancer Drugs 12: $847-852$

Kim SJ, Jin M, Lee E, Moon TC, Quan Z, Yang JH, Son KH, Kim KU, Son JK, Chang HW (2006) Effects of methyl gallate on arachidonic acid metabolizing enzymes: cyclooxygenase-2 and 5-lipoxygenase in mouse bone marrow-derived mast cells. Arch Pharm Res 29(10): 874-878

Kudryavtsev IA, Gudkova MV, Pavlova OM, Oreshkin AE, Myasishcheva NV (2005) Lipoxygenase pathway of arachidonic acid metabolism in growth control of tumor cells of different type. Biochemistry (Mosc) 70(12): $1396-1403$

Lee SJ, Lee HM, Ji ST, Lee SR, Mar W, Gho YS (2004) 1,2,3,4,6-Penta-Ogalloyl-beta-D-glucose blocks endothelial cell growth and tube formation through inhibition of VEGF binding to VEGF receptor. Cancer Lett 208(1): $89-94$

Lingfei K, Pingzhang Y, Zhengguo L, Jianhua G, Yaowu Z (1998) A study on $\mathrm{p} 16, \mathrm{pRb}, \mathrm{cdk} 4$ and cyclinD1 expression in non-small cell lung cancers. Cancer Lett 130(1-2): 93-101

Liu XH, Connolly JM, Rose DP (1996) Eicosanoids as mediators of linoleic acid-stimulated invasion and type IV collagenase production by a metastatic human breast cancer cell line. Clin Exp Metastasis 14(2): $145-152$

Liu Z, Schwimer J, Liu D, Greenway FL, Anthony CT, Woltering EA (2005) Black raspberry extract and fractions contain angiogenesis inhibitors. J Agric Food Chem 53: 3909-3915

Ma Z, Molavi O, Haddadi A, Lai R, Gossage RA, Lavasanifar A (2008) Resveratrol analog trans-3,4,5,4'-tetramethoxystilbene (DMU-212) mediates anti-tumor effects via mechanism different from that of resveratrol. Cancer Chemother Pharmacol 63(1): $27-35$

Madlener S, Illmer C, Horvath Z, Saiko P, Losert A, Herbacek I, Grusch M, Elford HL, Krupitza G, Bernhaus A, Fritzer-Szekeres M, Szekeres T (2007) Gallic acid inhibits ribonucleotide reductase and cyclooxygenases in human HL-60 promyelocytic leukemia cells. Cancer Lett 245(1-2): $156-162$

Madlener S, Rosner M, Krieger S, Giessrigl B, Gridling M, Vo TP, Leisser C, Lackner A, Raab I, Grusch M, Hengstschläger M, Dolznig H, Krupitza G (2009) Short 42 degrees $C$ heat shock induces phosphorylation and degradation of Cdc25A which depends on p38MAPK, Chk2 and 14.3.3. Hum Mol Genet 18(11): 1990-2000

Mailand N, Podtelejnikov AV, Groth A, Mann M, Bartek J, Lukas J (2002) Regulation of $\mathrm{G}(2) / \mathrm{M}$ events by $\mathrm{Cdc} 25 \mathrm{~A}$ through phosphorylationdependent modulation of its stability. EMBO J 21(21): $5911-5920$

Marks F, Muller-Decker K, Furstenberger G (2000) A causal relationship between unscheduled eicosanoid signaling and tumor development: 
cancer chemoprevention by inhibitors of arachidonic acid metabolism. Toxicology 153(1-3): 11-26

Nakamori S, Okamoto H, Kusama T, Shinkai K, Mukai M, Ohigashi $\mathrm{H}_{\text {, }}$ Ishikawa O, Furukawa H, Imaoka S, Akedo H (1997) Increased endothelial cell retraction and tumor cell invasion by soluble factors derived from pancreatic cancer cells. Ann Surg Oncol 4(4): 361-368

Nassar A, Radhakrishnan A, Cabrero IA, Cotsonis G, Cohen C (2007) COX-2 expression in invasive breast cancer: correlation with prognostic parameters and outcome. Appl Immunohistochem Mol Morphol 15(3): $255-259$

Nie D, Krishnamoorthy S, Jin R, Tang K, Chen Y, Qiao Y, Zacharek A, Guo Y, Milanini J, Pages G, Honn KV (2006) Mechanisms regulating tumor angiogenesis by 12-lipoxygenase in prostate cancer cells. J Biol Chem 281(27): $18601-18609$

Nie D, Nemeth J, Qiao Y, Zacharek A, Li L, Hanna K, Tang K, Hillman GG, Cher ML, Grignon DJ, Honn KV (2003) Increased metastatic potential in human prostate carcinoma cells by overexpression of arachidonate 12lipoxygenase. Clin Exp Metastasis 20(7): 657-663

Nie D, Tang K, Diglio C, Honn KV (2000) Eicosanoid regulation of angiogenesis: role of endothelial arachidonate 12-lipoxygenase. Blood 95(7): $2304-2311$

Ohigashi H, Shinkai K, Mukai M, Ishikawa O, Imaoka S, Iwanaga T, Akedo $\mathrm{H}$ (1989) In vitro invasion of endothelial cell monolayer by rat ascites hepatoma cells. Jpn J Cancer Res 80(9): 818-821

Oliver G, Alitalo K (2005) The lymphatic vasculature: recent progress and paradigms. Annu Rev Cell Dev Biol 21: 457-483

Paulitschke V, Schicher N, Szekeres T, Jäger W, Elbling L, Riemer AB, Scheiner O, Trimurtulu G, Venkateswarlu S, Mikula M, Swoboda A,

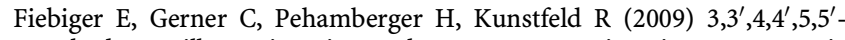
Hexahydroxystilbene impairs melanoma progression in a metastatic mouse model. J Invest Dermatol; e-pub ahead of print 3 December 2009. doi: 10.1038/jid.2009.376 PMID: 19956188

Park KS, Jeon SH, Oh JW, Choi KY (2004) p21Cip/WAF1 activation is an important factor for the ERK pathway dependent anti-proliferation of colorectal cancer cells. Exp Mol Med 36(6): 557-562

Perez-Pinera P, Menendez-Gonzalez M, del Valle M, Vega JA (2006) Sodium chloride regulates extracellular regulated kinase $1 / 2$ in different tumor cell lines. Mol Cell Biochem 293(1-2): 93-101

Pidgeon GP, Tang K, Rice RL, Zacharek A, Li L, Taylor JD, Honn KV (2003) Overexpression of leukocyte-type 12-lipoxygenase promotes W256 tumor cell survival by enhancing alphavbeta5 expression. Int J Cancer 105(4): 459-471

Ragione FD, Cucciolla V, Borriello A, Pietra VD, Racioppi L, Soldati G, Manna C, Galletti P, Zappia V (1998) Resveratrol arrests the cell division cycle at S/G2 phase transition. Biochem Biophys Res Commun 250: 53 - 58

Renaud S, De Lorgeril M (1992) Wine, alcohol platelets, and the French paradox for coronary heart disease. Lancet 339: 1523-1526

Richard JL (1987) Coronary risk factors. The French paradox. Arch Mal Coeur Vaiss 80: 17-21
Rose DP, Connolly JM (2000) Regulation of tumor angiogenesis by dietary fatty acids and eicosanoids. Nutr Cancer 37(2): 119-127

Saiko P, Szakmary A, Jaeger W, Szekeres T (2008) Resveratrol and its analogs: defense against cancer, coronary disease and neurodegenerative maladies or just a fad? Mutat Res 658(1-2): 68-94

Saiko P, Ozsvar-Kozma M, Bernhaus A, Jaschke M, Graser G, Lackner A, Grusch M, Horvath Z, Madlener S, Krupitza G, Handler N, Erker T, Jaeger W, Fritzer-Szekeres M, Szekeres T (2007) $N$-hydroxy- $N^{\prime}-(3,4$, 5-trimethoxyphenyl)-3,4,5-trimethoxy-benzamidine, a novel resveratrol analog, inhibits ribonucleotide reductase in HL-60 human promyelocytic leukemia cells: synergistic antitumor activity with arabinofuranosylcytosine. Int J Oncol 31(5): $1261-1266$

Salucci M, Stivala LA, Maiani G, Bugianesi R, Vannini V (2002) Flavonoids uptake and their effects on cell cycle of human colon adenocarcinoma cells (Caco2). Br J Cancer 86: 1645-1651

Schoppmann SF, Soleiman A, Kalt R, Okubo Y, Benisch C, Nagavarapu U, Herron GS, Geleff S (2004) Telomerase-immortalized lymphatic and blood vessel endothelial cells are functionally stable and retain their lineage specificity. Microcirculation 11(3): 261-269

Sipos B, Kojima M, Tiemann K, Klapper W, Kruse ML, Kalthoff H, Schniewind B, Tepel J, Weich H, Kerjaschki D, Kloppel G (2005) Lymphatic spread of ductal pancreatic adenocarcinoma is independent of lymphangiogenesis. J Pathol 207(3): 301 -312

Sohi KK, Mittal N, Hundal MK, Khanduja KL (2003) Gallic acid, an antioxidant, exhibits antiapoptotic potential in normal human lymphocytes: a Bcl-2 independent mechanism. J Nutr Sci Vitaminol (Tokyo) 49: $221-227$

Sridhar SB, Sheetal UD, Pai MR, Shastri MS (2005) Preclinical evaluation of the antidiabetic effect of Eugenia jambolana seed powder in streptozotocin-diabetic rats, Braz. J Med Biol Res 38: 463-468

Sun J, Chu YF, Wu X, Liu RH (2002) Antioxidant and antiproliferative activities of common fruits. J Agric Food Chem 50: 7449-7454

Tsang CM, Lau EP, Di K, Cheung PY, Hau PM, Ching YP, Wong YC, Cheung AL, Wan TS, Tong Y, Tsao SW, Feng Y (2009) Berberine inhibits Rho GTPases and cell migration at low doses but induces G2 arrest and apoptosis at high doses in human cancer cells. Int J Mol Med 24(1): $131-138$

Uchide K, Sakon M, Ariyoshi H, Nakamori S, Tokunaga M, Monden M (2007) Cancer cells cause vascular endothelial cell (vEC) retraction via 12(S)HETE secretion; the possible role of cancer cell derived microparticle. Ann Surg Oncol 14(2): 862-868

Whang WK, Park HS, Ham IH, Oh M, Namkoong H, Kim HK, Hwang DW, Hur SY, Kim TE, Park YG, Kim JR, Kim JW (2005) Methyl gallate and chemicals structurally related to methyl gallate protect human umbilical vein endothelial cells from oxidative stress. Exp Mol Med 37(4): $343-352$

Wolfe K, Wu X, Liu RH (2003) Antioxidant activity of apple peels. J Agric Food Chem 51: 609-614 